\title{
PENGATURAN PERLINDUNGAN HAK CIPTA PERMAINAN VIDEO
}

\author{
Nusan Indah Permata Sari, Fakultas Hukum Universitas Udayana, e-mail: \\ nusanindah1609@gmail.com \\ A.A. Gede Agung Dharmakusuma, Fakultas Hukum Universitas Udayana, e- \\ mail: agung_dharmakusuma@unud.ac.id
}

doi: https://doi.org/10.24843/KS.2020.v08.i08.p01

\begin{abstract}
ABSTRAK
Tujuan penulisan jurnal ilmiah ini adalah untuk mengetahui pengaturan permainan video dalam Undang-Undang Hak Cipta dan mengetahui bagaimana perlindungan hukum hak cipta terhadap pelanggaran permainan video. Tulisan ini menggunakan metode penelitian hukum normatif dengan menggunakan pendekatan perundang-undangan. Hasil dari penelitian ini menunjukkan bahwa terdapat kekaburan norma pada Undang-Undang Hak Cipta yaitu pada ketentuan pasal 40 ayat (1) huruf $r$ "permainan video". Kekaburan norma ini terlihat jelas karena tidak adanya penjelasan lebih lanjut terkait dengan pengertian permainan video serta pengklasifikasiannya. Selain itu terlihat jelas pula bahwa terdapat kekosongan norma terkait dengan sanksi bagi pelanggar hak moral pencipta yang tidak dilakukan tidak untuk kegiatan komersiil. Selanjutnya kesimpulan kedua bahwa permainan video merupakan salah satu objek dari suatu ciptaan yang dilindungi oleh Undang-Undang Hak Cipta yang perlindungannya berlaku selama 50 tahun sejak permainan video tersebut dipublikasikan. Berdasarkan ketentuan pasal 95 Undang-Undang Hak Cipta, pencipta atau pemegang hak cipta atau ahli waris dari pencipta permainan video dapat mengajukan tuntutan ganti rugi ke Pengadilan Niaga kepada pelaku pelanggaran hak ekonomi pencipta permainan video.
\end{abstract}

Kata Kunci: Pengaturan, Hak Cipta, Permainan Video

\begin{abstract}
The purpose of this scientific journal is to know the rules of the video games in the Copyright law and to know how the copyright legal protection against video games violations. In this paper, the research method used is normative legal research which uses a statutory approach. The result of this journal are indicate there is a blurry norm in Article 40 paragraph letter $r$ of Copyright law. The ambiguity of norm is cleary seen because there is no further explanation related to the understanding of video games and their classification and it is also cleary that there are void norm related to sanction for violators of the creator's moral rights wich are not carried out not for commercial activities. Then, the second conclusions is that video games are one of the object of a creation that get protection from Copyright laws, the protection os valid for 50 years since the video games was published. Based on the Article 95 of Copyright law, the creator or copyright holder or the heirs of creator of video games can submit compensations claims to the Commersial Court to the perpretators of violations of the economic rights of the video games creator's.
\end{abstract}

Key Words: Regulation, Copyright, Video Games 


\section{Pendahuluan}

\subsection{Latar Belakang}

Manusia adalah makhluk individu yang merupakan suatu ciptaan Tuhan yang sangat spesial. Hal ini dikarenakan oleh manusia memiliki akal pikiran, budi dan rasa (nafsu), maka daripada itu manusia sering disebut sebagai mahkluk ciptaan Tuhan yang paling sempurna. ${ }^{1}$ Kemampuan berpikir manusia tersebut tidak hanya untuk menyelesaikan masalah-masalah sehari-hari saja, namun manusia juga mampu untuk menciptakan sesuatu yang berwujud nyata maupun virtual. Hasil ciptaan yang berasal dari olah pikir manusia tersebut memiliki hak yang harus dilindungi. Hak tersebut disebut sebagai Kekayaan Intelektual (selanjutnya disebut sebagai KI), dimana Kekayaan Intelektual ini dilindungi oleh pemerintah Indonesia. Hak Atas Kekayaan Intelektual adalah suatu hak yang eksklusif yang diberikan oleh pemerintah Indonesia melalui undang-undang atas karya ciptanya yang mencangkup ilmu pengetahuan, teknologi, seni dan sastra. ${ }^{2}$ Produk-produk Kekayaan Intelektual sendiri berasal dari kinerja otak dengan pengorbanan waktu dan biaya untuk menghasilkan suatu produk debgan nilai ekonomi yang tinggi. ${ }^{3}$

Kekayaan Intelektual melindungi permainan video sebagai salah satu objek yang dilindungi. ${ }^{4}$ Permainan video ini dilindungi hak cipta melalui ketentuan pasal 40 ayat (1) huruf r pada UU No. 28 Tahun 2014 tentang Hak Cipta. Namun, pada UndangUndang Hak Cipta terjadi kekaburan norma terkait dengan penjelasan definisi permainan video. Sedangkan permainan video terdapat banyak jenisnya, dan permainan video ada yang berbentuk software komputer. Sehingga terjadi ketidakjelasan antara perbedaan antara permainan video dengan program komputer. Selain adanya kekaburan norma, terdapat permasalahan terkait pelanggaran karya cipta permainan video. Meskipun Undang-Undang Hak Cipta telah memberikan dasar hukum terkait dengan perlindungan hak cipta permainan video, namun faktanya masih terdapat pelanggaran-pelanggaran yang terjadi di dunia nyata baik oleh para pengguna permainan video maupun oleh para pengembang permainan video yang tentunya akan sangat merugikan pihak dari pencipta permainan video yang telah mengorbankan banyak waktu, tenaga dan biaya untuk menghasilkan permainan video tersebut. ${ }^{5}$ Contoh nyata adanya suatu pelanggaran terhadap hak cipta permainan video oleh pengguna permainan permainan video ini adalah pengunduhan permainan video bajakan seperti The Sims 4. Permainan video terkenal seperti The Sims 4 yang diterbitkan oleh Electronic Arts ini dibandrol dengan harga yamg cukup tinggi, yaitu

1 Saudah, Siti., \& Nusyirwan. "Konsep Manusia Sempurna." Jurnal Filsafat Universitas Gajah Mada 14, no. 2 (2004), 185 -186. https://doi.org/10.22146/jf.31332.

2 Yogiswari, Ni Made Dharmika., \& Mudana, Nyoman. "Perlindungan Hukum Hak Cipta Lagu Terhadap Kegiatan Aransemen." Kertha Semaya: Journal Ilmu Hukum 8, no. 5 (2020), 699.

3 Weda Sari, Ni Komang Ayu., \& Wiryawan, I Wayan. "Pengaturan Perlindungan Hukum Atas Obat Tradisional Berdasarkan Perspektif Hak Kekayaan Intelektual." Kertha Semya: Journal Ilmu Hukum 6, no. 2 (2018), 7.

4 Andini, Maria Paulina., Kusumadara, Afifah., \& Pawestri, Diah. "Perlindungan Hukum Terhadap Pemegang Hak Cipta Permainan Video Atas Tindakan Pembajakan Online (Kajian Berdasarkan Konsep Kovergensi Telematika Dan Undang-Undang Nomor 28 Tahun 2014 tentang Hak Cipta)." Jurnal Hukum (2018), 1.

5 Paserangi, Hasbir. "Perlindungan Hukum Hak Cipta Software Program Komputer Di Indonesia." Jurnal Hukum Ius Quia Iustum 18 (2011), 22. 
Rp 562.000,- untuk versi originalnya saja dan bahkan untuk permainan video The Sims 4 versi lengkapnya bisa mencapai total harga 10 juta rupiah. Tentu saja harga permainan ini terbilang cukup fantastis di bandingkan dengan mengunduh versi bajakannya secara tidak sah di internet secara gratis atau membeli versi bajakannya yang dalam bentuk kepingan CD/VCD. Pengunduhan permainan video bajakan ini tentu akan sangat merugikan pihak developer permainan video.

Banyaknya permainan video yang tersedia saat ini menyebabkan banyak perusahaan pengembang permainan video yang semakin gencar untuk bersaing memasarkan produknya sebagai produk terbaik. ${ }^{6}$ Ketatnya persaingan antar perusahaan pengembang permain video tersebut menyebabkan beberapa perusahaan yang memilih untuk menggunakan jalan pintas tanpa harus bersusah payah berpikir keras untuk menciptakan karyanya yang berupa permainan video. Cara pintas tersebut yaitu dengan membajak permainan video. Hal ini terjadi menimpa perusahaan pengembang permainan video asal Indonesia yaitu Toge Production dengan permainan yang berjudul Infectonator, Touchten dengan judul permainan Infinite Sky dan Qajoo dengan judul aplikasi Run Princess Run. ${ }^{7}$ Bahkan tindakan tersebut bukan hanya pembajakan biasa (mengedarkan software secara gratis di internet) melainkan sampai dengan mengubah pencipta permainan video tersebut dan permainan tersebut disusupi virus yang dapat mencuri informasi pengguna. Berdasarkan atas penjabaran diatas, penulis tertarik untuk menulis penelitian jurnal ilmiah yang berjudul "Pengaturan Perlindugan Hak Cipta Permainan Video"

\subsection{Rumusan Masalah}

Berdasarkan uraian latar belakang masalah diatas, dikaji dua permasalahan sebagai berikut:

1. Bagaimanakah pengaturan pormainan video berdasarkan Undang-Undang Hak Cipta?

2. Bagaimanakah perlindungan hukum terhadap permainan video berdasarkan ketentuan Undang-Undang Hak Cipta?

\subsection{Tujuan Penulisan}

Tujuan penluisan jurnal ilmiah yang berjudul "Pengaturan Perlindungan Hak Cipta Permaiman Video" ini untuk mengetahui peraturan terkait dengan permainan video pada Undang-Undang Hak Cipta serta perlindungan hukum terhadap hak cipta atas suatu pelanggaran terhadap permainan video di Indonesia. Urgensi penulisan jurnal ilmiah ini adalah untuk sarana pengembangan ilmu pengetahuan, selain itu sebagai refrensi untuk penambahan ilmu pengetahuan kepada masyarakat khususnya kepada pencipta dan pengembang permainan video, kepada para pengguna permainan video serta kepada praktisi hukum karena kurang jelasnya pengaturan terkait permainan video dan terdapat banyaknya peredaran permainan video bajakan di masyarakat secara nyata maupun di internet.

6 Suangga, Anisa., Ropi, Helwiyah., \& Mardhiyah, Ai. "Hubungan Aktivitas Bermain Video Game Dengan School Myopia Pada Siswa-Siswi SD ASY Syifa 1 Bandung." Majalah Keperawatan Universitas Padjajaran 13, No. 2 (2011), 2.

7 Panji, Aditya. 3 Game Android Buatan Indonesia Dibajak. 2014. Retrieved from: https://tekno.kompas.com/read/2014/04/04/1455115/3Game.Android.Buatan.Indonesia. Dibajak (Diakses pada tanggal 16 Juni 2020) 


\section{Metode Penelitian}

Penelitian jurnal ilmiah dengan judul "Pengaturan Perlindungan Hak Cipta Permaiman Video" ini adalah menggunakan metode hukum normatif yang menggunakan pendekatan perundang-undangan. Penelitian jurnal ilmiah ini cendrung lebih banyak menggunakan bahan hukum sekunder. Teknik sistem kartu (card system) digunakan untuk menelaah literatur-literatur yang relevan kemudian literatur yang didapat dipilah sedemikian rupa dan dicocokkan dengan permasalahan yang dibahas.

\section{Hasil dan Pembahasan}

\subsection{Pengaturan Permainan Video Berdasarkan UU No 28 Tahun 2014 Tentang Hak} Cipta

Undang-Undang Hak Cipta melindungi permainan video sebagai salah satu objek karya cipta seseorang yang dilindungi. Namun dalam kenyataannya ketentuan penjelasan pasal 40 ayat (1) huruf tidak penjelasan lebih lanjut terkait dengan pengertian permainan video, melainkan hanya terdapat frasa "Cukup jelas" saja tanpa adanya keterangan-keterangan lebih lanjut. Hal ini tentu saja membuat praktisipraktisi hukum maupun praktisi-praktisi di bidang ilmu teknologi dan informasi merasa kurang jelas. Selain itu, Undang-Undang Hak Cipta maupun ketentuan peraturan perundang-undangan lainnya masih tidak mengatur lebih lanjut dan secara mendetail tentang definisi, klasifikasi, jenis dan hal-hal lain yang masih berkaitan dengan permainan video. 8 Jika dilihat dari bentuknya, permainan video ini biasa disajikan dalam bentuk software. Software atau yang dapat disebut sebagai perangkat lunak merupakan suatu program yang berfungsi untuk meberkian perintah kepada komputer untuk mengontrol, mendukung dan mengolah data. ${ }^{9}$ Apabila dilihat dari definisinya, software ini dekat dengan definisi dari program komputer. Program komputer sendiri telah didefinisikan oleh Undang-Undang Hak Cipta melalui ketentuan pasal 1 ayat 9 yang menytakan bahwa "Program Komputer adalah seperangkat instruksi yang diekspresikan dalam bentuk bahasa, kode, skema atau dalam bentuk apapun yang ditujukan agar komputer bekerja melakukan fungsi tertentu atau untuk mencapai hasil tertentu". Namun apabila kita telaah lagi lebih lanjut, kita dapat berpendapat bahwa permainan video yang berbentuk software yang disediakan pada perangkat komputer ini dapat dimasukkan ke dalam katagori program kumputer. Namun tidaklah relevan jika permainan video yang terdapat dalam perangkat lain juga dimasukkan ke dalam kategori program komputer. Selain itu, jika kita lihat dari proses pembuatannya, permainan video dapat dikategorikan sebagai suatu karya cipta yang sangat kompleks. Hal ini dikarenakan pembuatan permainan video tidak hanya berdasarkan atas membuat software yang berupa kodekode tertentu saja, melainkan permainan video juga terdiri atas ciptaan lain yang berupa desain, gambar-gambar animasi, musik, tokoh, dan lain sebagainya.

Apabila dilihat dari sejarah pembuatan suatu permainan, sebenarnya permainan video yang awalnya hanya disediakan dalam bentuk program komputer saja, dengan

8 Dilaga, Robby Akhmad Surya. "Perlindungan Hukum Terhadap Pencipta Software Game Dalam Perspektif Undang-Undang Nomor 28 Tahun 2014 Tentang Hak Cipta." Jurnal Ius Kajian Hukum Dan Keadilan 4, no. 2 (2016), 24. http://dx.doi.org/10.12345/ius.v4i2.285

9 Wijaya, Ketut Rama., Windari, Ratna Artha., Yuliartini, Ni Putu Rai. “Akibat Hukum Pelanggaran Hak Cipta Software Video Games Bajakan Ditinjau Dari Undang-Undang Nomor 28 Tahun 2014 Tentang Hak Cipta." Jurnal Komunitas Iustitia 1, no. 3 (2018), 91-100. 
disertai adanya perkembangan jaman, perkembangan ilmu pengetahuan serta perkembangan teknologi, permainan video tidak lagi hanya diperuntukkan untuk komputer saja, melainkan dapat pula diperuntukkan untuk perangkat lain seperti smartphone (telepon pintar), atau bahkan tersedia dalam bentuk konsol permainan video seperti Nitendo Entertain System, Xbox, Wii, Playstation dan lain sebagainya. ${ }^{10}$ Sehingga dapat dikatakan permainan video ini juga dapat diklasifikasikan ke dalam pasal 40 ayat (1) huruf p Undang-Undang Hak Cipta yang menyatakan "kompilasi Ciptaan atau data, baik dalam format yang dapat dibaca dengan Program Komputer maupun media lainnya". Maka hal ini akan menimbulkan suatu ketidakjelasan terhadap penormaan terkait dengan ketentuan pasal 40 ayat (1) huruf $\mathrm{p}$, huruf $\mathrm{r}$ dan huruf s pada Undang-Undang Hak Cipta yang akan menyebabkan para praktisipraktisi hukum maupun praktisi-praktisi pada bidang teknologi informasi merasa kurang jelas terkait dengan permainan video ini.

\subsection{Perlindugnan Hukum Terhadap Pelanggaran Hak Cipta Permainan Video Berdasarkan Undang-Undang Hak Cipta}

Pasal 1 ayat (1) Undang-Undang Hak Cipta menyatakan bahwa "Hak Cipta adalah hak eksklusif pencipta yang timbul secara otomatis berdasarkan prinsip deklaratif setelah suatu ciptaan diwujudkan dalam bentuk nyata tanpa mengurangi pembatasan sesuai dengan ketentuan peraturan perundang-undangan". Berdasarkan ketentuan pasal 1 ayat (1) diatas dapat diketahui bahwa suatu ciptaan dapat dilindungi hak ciptanya secara otomatis. ${ }^{11}$ Hak cipta ini bersifat eksklusif dan mendapat suatu perlindungan hukum. ${ }^{12}$ Hak eksklusif ini berlaku apabila seorang pencipta telah mampu untuk mewujudkan hasil olah pikirnya dan telah menunjukkan keaslian ciptaannya tersebut. ${ }^{13}$ Hak cipta ini diberikan atas dasar bahwa semua orang mempunyai kemampuan untuk mengolah pikirannya, namun tidak semua orang dapat mengolah otaknya semaksimal mungkin untuk menghasilkan suatu karya intelektual yang bernilai sangat tinggi. ${ }^{14}$ Maka daripada hal tersebut diatas, perlindungan terhadap suatu hasil ciptaan dari seseorang sebagai pencipta ini menjadi sangat penting. Selain dengan diberikannya perlindungan hukum, pencipta ini diberikan suatu penghargaan dan juga pengakuan oleh pemerintah. ${ }^{15}$

Permainan video merupakan salah satu objek ciptaan yang dilindungi oleh Undang-Undang Hak Cipta. Permainan video berdasarkan ketentuan Pasal 59 ayat (1)

10 Caesar, Rio. “Kajian Pustaka Perkembangan Genre Games Dari Masa Ke Masa." Journal of Animation And Games Studies 1, No. 2 (2015): 113-134. https://doi.org/10.24821/jags.v1i2

11 Dharmawan, Ni Ketut Supasti., Landra, Putu Tuni Cakabawa., Wiryawan, I Wayan., Bagiastra, I Nyoman., \& Samsithawrati, Putu Aras. “Ketentuan Hak Cipta Berkaitan Dengan Pembayaran Royalti Atas Pemanfaatan Ciptaan Lagu Secara Komersial Pada Restoran/Cafe Di Daerah Pariwisata Jimbaran Bali." Buletin Udayana Mengabdi 16, no. 1 (2017), 10.

12 Dharmawan, Ni Ketut Supasti., dkk. Harmonisasi Hukum Kekayaan Intelektual Indonesia. (Denpasar, Swasta Nulus, 2018), 21.

13 Sudaryat, Sudjana, \& Permata, Rika Ratna. Hak Kekayaan Intelektual: Memahami Pinsp Dasar, Cakupan Dan Undang-Undang Yang Berlaku.(Bandung, Oase Media, 2010), 21.

14 Paramita, Ni Made Gearani Larisa., \& Mudana, Nyoman. "Perlindungan Hukum Hak Cipta Film Anime Yang Diunggah Oleh Komunitas Fanhub Tanpa Izin Pencipta." Kertha Negara: Journal Ilmu Hukum 7, no. 11, (2019), 3.

15 Hutagalung, Sophar Maru. Hak Cipta: Kedudukan Dan Perannya Dalam Pembangunan. (Jakarta, Sinar Grafika, 2012), 4. 
Undang-Undang Hak Cipta dapat dilindungi selama 50 tahun sejak permainan video tersebut dipublikasikan. Suatu permainan video secara otomatis mendapatkan perlindungan hak cipta setelah permainan video tersebut diumumkan bahwa telah diwujudkan dalam bentuk nyata. ${ }^{16}$ Berkaitan dengan permasalahan adanya pengunduhan permainan video seperti The Sims 4 di internet secara tidak sah oleh pengguna permainan video, ini merupakan salah satu tindak pelanggaran atas hak cipta permainan video dimana pengguna permainan video mengurangi pemanfaatan hak ekonomi dari pencipta yang dimaksudkan dalam ketentuan Pasal 1 angka (21) Undang-Undang Hak Cipta yaitu Royalti yang berupa sejumlah imbalan berupa uang. Pelanggaran terhadap hak ekonomi pencipta ini dapat diajukan tuntutannya oleh pencipta atau pemegang hak cipta atau oleh ahli warisnya melalui Pengadilan Niaga sebagaimana dimaksudkan dalam ketentuan Pasal 95 Undang-Undang Hak Cipta. Pelanggaran hak cipta oleh pengguna permainan video dapat di mintai ganti kerugian oleh pencipta atau pemegang hak cipta atau ahli warisnya.

Kemudian berkaitan dengan permasalahan kedua yaitu dengan jenis pelanggaran hak cipta pembajakan permainan video ciptaan perusahaan permainan video asal Indonesia oleh pengembang yang menamai dirinya sebagai "Tuna Fish" dan "Banana Games" yang sampai mengubah isi dari permainan video dengan mencantumkan namanya pada permainan video tersebut, menambahkan virus dan mencuri informasi pribadi dari pengguna permainan video tersebut merupakan salah satu pelanggaran terhadap hak cipta. Pelanggaran tersebut diantaranya adalah yaitu pelanggaran terhadap hak moral pencipta yang diantarnaya adalah mencantumkan nama palsu pada permainan video (pasal 5 ayat (1) huruf a) dan memodifikasi ciptaan dan menambahkan virus (pasal 5 ayat (1) huruf e). Namun dalam hal ini pelaku tidak dapat dituntut dan dikenai hukuman karena tidak ada peraturan yang mengatur terkait dengan sanksi atas pelanggaran terkait dengan hak moral yang dilakukan tidak untuk penggunaan secara komersiil. Serta berkaitan dengan dengan pencurian data pribadi pengguna permainan video juga masih belum terdapat peraturan perundangundangannya.

\section{Kesimpulan}

Terdapat 2 (dua) kesimpulan yang dapat penulis berikan dalam penulisan jurnal ilmiah ini yaitu adanya kekaburan norma pada ketentuan pasal 40 ayat (1) huruf $r$ Undang-Undang Nomor 28 Tahun 2014 tentang Hak Cipta. Dimana tidak adanya penjelasan yang lebih spesifik terkait dengan pengertian terkait dengan permainan video sehingga menimbulkan kerancuan antara pengertian permainan video dengan permainan video pada komputer dan dengan kompilasi data pada permainan video sehingga dapat menimbulkan para praktisi di bidang hukum maupun praktisi di bidang teknologi informasi merasa kurang jelas terhadap hal tersebut. Kemudian kesimpulan kedua yaitu permainan video dilindungi oleh Pemerintah Idnoensia dengan cara membuat regulasi terkait yaitu Undang-Undang Hak Cipta. Permainan video merupakan salah satu objek perlindungan hak cipta yang disebutkan pada ketentuan pasal 40 ayat (1). Perlindungan permainan video tersebut berlaku 50 tahun

16 Aristya Dewi, Dewa Ayu Pringga., \& Darmadi A. A. Sagung Wiratni. "Pengaturan Perlindungan Karya Cipta Fotografi Yang Diambil Tanpa Izin Melalui Media Sosial Berdasarkan Undang-Undang Nomor 28 Tahun 2014 tentang Hak Cipta." Ketha Semaya: Journal Ilmu Hukum 4, no. 2 (2008), 5. 
sejak diumumkannya permainan video oleh penciptanya. Perlindungan tersebut dapat berupa perlindungan terhadap hak moral dan hak ekonomi pencipta terhadap ciptaannya yang berupa permainan video tersebut. Untuk pelanggaran terhadap hak ekonomi dari pencipta yang dilakukan tidak untuk kegiatan komersiil dapat diajukan tuntutannya berupa ganti kerugian ke Pengadilan Niaga, hal ini diatur dalam ketentuan pasal 95 Undang-Undang Hak Cipta. Namun belum ada aturan yang jelas terkait dengan sanksi atas pelanggaran hak moral pencipta yang dilakukan tidak untuk kegiatan komersiil dan sanksi atas pencurian data pribadi pengguna permainan video.

Saran yang dapat penulis berikan pada penulisan jurnal ilmiah ini adalah pertama kepada Pemerintah Indonesia, diharapkan agar dapat lebih berhati-hati dalam membuat suatu peraturan perundang-undangan dan diharapkan pemerintah dapat merevisi ketentuan pada Undang-Undang Hak Cipta yang berkaitan dengan penjelasan terkait dengan pengertian permainan video, lebih memperjelas terkait dengan pengklasifikasian ciptaan yang dilindungi serta sanksi pelanggaran hak moral yang tidak digunakan untuk kegitan komersil. Kepada pengembang permainan video, diharapkan agar meningkatkan sistem keamanan pada permainan video tersebut untuk menghindari adanya pembajakan permainan video. Kepada para pengguna permainan video di Indonesia diharapkan agar lebih bijak lagi dan diharapkan untuk mematuhi aturan serta tidak melanggar hak cipta permainan video dengan mengunduh permainan video versi bajakan melainkan pengguna diharapkan mengunduh permainan video versi asli yang tersedia pada situs-situs web resmi.

\section{DAFTAR PUSTAKA}

Buku

Dharmawan, Ni Ketut Supasti., dkk. Harmonisasi Hukum Kekayaan Intelektual Indonesia, (Denpasar, Swasta Nulus, 2018).

Hutagalung, Sophar Maru. Hak Cipta: Kedudukan Dan Perannya Dalam Pembangunan. (Jakarta, Sinar Grafika, 2012).

Sudaryat, Sudjana, \& Permata, Rika Ratna. 2010. Hak Kekayaan Intelektual: Memahami Pinsp Dasar, Cakupan Dan Undang-Undang Yang Berlaku. (Bandung, Oase Media, 2010).

\section{Jurnal}

Andini, Maria Paulina., Kusumadara, Afifah., \& Pawestri, Diah. "Perlindungan Hukum Terhadap Pemegang Hak Cipta Permainan Video Atas Tindakan Pembajakan Online (Kajian Berdasarkan Konsep Kovergensi Telematika Dan Undang-Undang Nomor 28 Tahun 2014 tentang Hak Cipta)." Jurnal Hukum (2018).

Aristya Dewi, Dewa Ayu Pringga., \& Darmadi A. A. Sagung Wiratni. "Pengaturan Perlindungan Karya Cipta Fotografi Yang Diambil Tanpa Izin Melalui Media Sosial Berdasarkan Undang-Undang Nomor 28 Tahun 2014 tentang Hak Cipta." Ketha Semaya: Journal Ilmu Hukum 4, no. 2 (2008): 1-14.

Caesar, Rio. "Kajian Pustaka Perkembangan Genre Games Dari Masa Ke Masa." Journal of Animation And Games Studies 1, no. 2 (2015): 113-134.

Dharmawan, Ni Ketut Supasti., Landra, Putu Tuni Cakabawa., Wiryawan, I Wayan., Bagiastra, I Nyoman., \& Samsithawrati, Putu Aras. "Ketentuan Hak Cipta Berkaitan Dengan Pembayaran Royalti Atas Pemanfaatan Ciptaan Lagu Secara 
Komersial Pada Restoran/Cafe Di Daerah Pariwisata Jimbaran Bali." Jurnal Program Hukum Bisnis Fakultas Hukum Universitas Udayana 16, no. 1 (2017): 7-13.

Dilaga, Robby Akhmad Surya. "Perlindungan Hukum Terhadap Pencipta Software Game Dalam Perspektif Undang-Undang Nomor 28 Tahun 2014 Tentang Hak Cipta." Jurnal Ius Kajian Hukum Dan Keadilan 4, no. 2 (2016): 22-33.

Paramita, Ni Made Gearani Larisa., \& Mudana, Nyoman. "Perlindungan Hukum Hak Cipta Film Anime Yang Diunggah Oleh Komunitas Fanhub Tanpa Izin Pencipta." Kertha Negara: Journal Ilmu Hukum 7, no. 11, (2019): 1-18.

Paserangi, Hasbir. "Perlindungan Hukum Hak Cipta Software Program Komputer Di Indonesia." Jurnal Hukum Ius Quia Iustum 18 (2011): 20-35.

Saudah, Siti., \& Nusyirwan. "Konsep Manusia Sempurna." Jurnal Filsafat Universitas Gajah Mada 14, no. 2 (2004): 185-191.

Suangga, Anisa., Ropi, Helwiyah., \& Mardhiyah, Ai. "Hubungan Aktivitas Bermain Video Game Dengan School Myopia Pada Siswa-Siswi SD ASY Syifa 1 Bandung." Majalah Keperawatan Universitas Padjajaran 13, no. 2 (2011).

Weda Sari, Ni Komang Ayu., \& Wiryawan, I Wayan. "Pengaturan Perlindungan Hukum Atas Obat Tradisional Berdasarkan Perspektif Hak Kekayaan Intelektual." Kertha Semya: Journal Ilmu Hukum 6, no. 2 (2018): 1-15.

Wijaya, Ketut Rama., Windari, Ratna Artha., Yuliartini, Ni Putu Rai. “Akibat Hukum Pelanggaran Hak Cipta Software Video Games Bajakan Ditinjau Dari UndangUndang Nomor 28 Tahun 2014 Tentang Hak Cipta." Jurnal Komunitas Iustitia 1, no. 3 (2018): 91-100.

Yogiswari, Ni Made Dharmika., \& Mudana, Nyoman. "Perlindungan Hukum Hak Cipta Lagu Terhadap Kegiatan Aransemen." Kertha Semaya: Journal Ilmu Hukum 8, no. 5 (2020): 699-708.

\section{Internet}

Panji, Aditya. 3 Game Android Buatan Indonesia Dibajak. 2014. Retrieved from: https://tekno.kompas.com/read/2014/04/04/1455115/3Game.Android.Buatan. Indonesia.Dibajak.

Peraturan Perundang-Undangan

Indonesia, Undang-Undang Nomor 28 Tahun 2014 tentang Hak Cipta 